Nataša PICHLER-MILANOVIĆ

\title{
Interurbane transformacije v srednji in vzhodni Evropi ${ }^{[1]}$
}

Prispevek poskuša razložiti nekatere vidike o smislu, obsegu, razlogu in prostoru, kjer mesta srednje in vzhodne Evrope doživljajo globalizacijske procese oziroma so integrirana $v$ svetovno gospodarstvo. Nadalje, ali so kje bolj pod vplivi makroregionalnih (mednarodnih) sil, kot sta širitev Evrope in integracija (evropeizacija), v kolikšnem obsegu in zakaj. S tem poskuša prispevek ovrednotiti medsebojno vzajemno igro globalnih in makroregionalnih sil z lokalnimi in državnimi silami politične in ekonomske tranzicije pri oblikovanju sprememb mest srednje in vzhodne Evrope.

\section{Globalizacija in oblikovanje svetovnih mest}

Globalizacijo lahko opredelimo kot proces, ki razširja, poglablja in pospešuje funkcionalno integracijo, tekmovalnost in sodelovanje, odvisnost ali medsebojno odvisnost mest in njihovih regij prek (med)narodnih meja, celin in oceanov. Izraz globalizacija je kot takšen moral počakati do 90 . let prejšnjega stoletja, ko so širši, celovitejši pristopi, pospešeni s koncem hladne vojne, začeli upoštevati pestrost medsebojno odvisnih kulturnih, gospodarskih, političnih, družbenih in tehnoloških razsežnosti. Polemika o globalizaciji se odvija v treh glavnih prepoznavnih šolah mišljenja na to temo (Held et al., 1999): - Hiperglobalizatorji kot Ohmae (1990, 1995), ki so zavezani ideji o vsemogočnem in vseprežemajočem globalizacijskem procesu. Prikazuje se jim »brezmejni svet «, v katerem globalni trg in tehnološke sile podjarmljajo nacionalne države, razgrajujejo njihovo nacionalno suverenost in posledično silnice $\mathrm{v}$ mestih in regijah, ki jih sestavljajo.

- Drugačno stališče zavzemajo t. i. skeptiki, kot sta Hirst in Thompson (1996). Doka-
The article attempts to provide some insights into whether, how far, why and where cities in Central and Eastern Europe are experiencing globalisation processes, and are being integrated into the world economy. Furthermore, whether, how far, why and where they are more strongly subject to macro-regional (international) forces such as European enlargement and integration ("EU-isation«). Therefore, the article attempts to evaluate the interplay of global and macro-regional forces with local and national forces of political and economic transition in shaping the transformation of cities in Central and Eastern Europe.

zujejo, da je bila globalizacija že dobro uveljavljena ob koncu 19. st., ko je dosegla vrhunec. V zadnjih desetletjih se svet predvsem reorganizira $\mathrm{v}$ nekaj večjih makroregionalnih blokih (kot sta EU ali Nafta), ki kažejo vedno bolj trdno notranjo kohezijo in medsebojno odvisnost ter manjšo odvisnost navzven. Za njih je svetovno gospodarstvo danes bolj razdrobljeno, nacionalne ali lokalne kulturne in politične sile pa imajo bistveno več moči kot v prejšnjih obdobjih.[2]

- Obstajajo še »transformacionalisti« kot sta Giddens (1990, 1996) ali Rosenau (1997), za katere je globalizacija zelo sodoben pojav brez zgodovinskega precedensa, kajti večina narodov in mest doživlja globoke spremembe, ko se poskušajo prilagoditi ne le bolj soodvisnemu, ampak tudi manj predvidljivemu svetu.

Sočasni razvoj in sožitje teh različnih stališč in razprav podčrtujeta realnost globalizacije in sta izraz okolja, v katerem nastajajo takojšnji interaktivni prenos in širjenje idej in znanja ter njihovo empirično preverjanje. Hitri razvoj raznolikosti pristopov, ki ponuja različne ugotovitve tako v sklopu teh treh glavnih šol mišljenja kot znotraj njih samih, ponuja koristno izhodišče za ovrednotenje te kom-
Globalizacija Oblikovanje svetovnih mest Srednja Evropa Vzhodna Evropa

Central Europe Globalisation Eastern Europe World city formation 
pleksne realnosti na primeru sedanje transformacije mest $\mathrm{v}$ srednji in vzhodni Evropi.

Hitra integracija gospodarstev v svetovnem merilu zaradi globalizacije je zelo opazna od 80. let dalje zaradi zbliževanja smernic, ki odsevajo strukturne prilagoditve in internacionalizacijo proizvodnje, tehnološke inovacije in na znanju temelječe dejavnosti (Lo in Yeung, 1998). Strukturne prilagoditve, ki segajo v proizvodnje, uporabo virov, finančne transakcije in ustvarjanje bogastva, so tudi spodbudile proces oblikovanja svetovnega ali globalnega mesta ter preoblikovanje ekonomskih, socialnih in fizičnih struktur mest in njihovo konkurenčnost znotraj različnih urbanih mrež. [1] Istočasno proces globalizacije, opredeljen kot rastoča čezmejna funkcionalna integriranost ekonomskih in drugih dejavnosti, stopnjuje medsebojno odvisnost večjih mest, ki so locirana po vsem svetu kot vedno pomembnejša vozlišča trgovskih, kapitalskih, človeških in informacijskih tokov (glej Friedman, 1986, 1995, 2001; Knox in Taylor, 1995; Sassen, 1991, 1994; itd.).

Od konca 1980 srednje- in vzhodnoevropske države preživljajo politični, ekonomski in institucionalni prehod iz različnih oblik socialističnih struktur $\mathrm{v}$ demokratične in tržnoekonomske sisteme. Globalizacijo kot izraz in pojem lahko tolmačimo kot dvojni proces. Prvič kot obliko tranzicije ali strukturnega prilagajanja, premik od socialističnih družb $\mathrm{k}$ demokratičnim družbam in tržnim gospodarstvom ter kot internacionalizacijo ali funkcionalno (re) integracijo $\mathrm{v}$ globalne procese po koncu hladne vojne. Drugič, predvideni pristop $\mathrm{k}$ polnopravnemu članstvu $\mathrm{v}$ Evropski uniji (EU) pomeni popolnoma novo fazo institucionalnega razvoja. Sistematični proces širjenja EU in integracije - evropeizacije ali bolje EU-izacije vrednot, standardov, pravil in politik - lahko tako tolmačimo kot specifični način globalizacije srednje in vzhodne Evrope v posebnem makroregionalnem kontekstu, ki ima namen doseči globalno konkurenčnost $\mathrm{v} 21$. stoletju.

$\mathrm{V}$ tem pogledu se pritiski svetovnega gospodarstva, zlasti $v$ smislu konkurenčnosti mest pri privabljanju kapitalskih investicij in izboljševanju položaja v mednarodni hierarhiji mest, transnacionalnih in čezmejnih urbanih mrežah, ravno tako nanašajo na srednjo in vzhodno Evropo kot na katerokoli drugo območje na svetu (Enyedi, 1998; Keivani et al. 2001; Marcuse in van Kempen, 2000; Musil, 1993). Zatorej je potrebno šele opredeliti oblikovanje svetovnega (ali globalnega) mesta ter položaj srednje- in vzhodnoevropskih glavnih in drugih velikih mest znotraj širše globalne in evropske urbane hierarhije.

Oblikovanje svetovnega mesta je proces, $s$ katerim globalno gospodarstvo deluje na mesta in preobraža njihove socialne, ekonomske in fizične razsežnosti. Osredotoča se na vlogo upravljalskih in nadzornih dejavnosti na velikih urbanih območjih (Friedman, 1986; Sassen, 1991, 1994), kot so lociranje glavnih sedežev transnacionalnih korporacij in mednarodnih institucij, poslovne storitve, prometna dostopnost, število prebivalcev, raziskovalne in izobraževalne ustanove ter kongresne in razstavne funkcije.

Toda oblikovanje svetovnega mesta je nepretrgan in raznovrsten ali večstranski proces. Pojav specializiranih ali regionalnih funkcionalnih mestnih sistemov na novo opredeljuje vloge posameznih mest ali skupin mest v globalni urbani hierarhiji. Mesta, ki so vključena $v$ funkcionalne mestne sisteme ( $\mathrm{tj}$. čezmejne regionalne urbane mreže), so tudi izpostavljena procesu oblikovanja svetovnega mesta. Njihova vključenost $\mathrm{v}$ sistem oz. urbane mreže neposredno učinkuje na obliko, strukturo in razvoj mesta. Po Brennerju (1999) oblikovanje svetovnega mesta kot dela teritorialne reorganizacije pomeni, da mesta izvajajo fizično prestrukturiranje svojih intraurbanih vzorcev, da bi dosegla učinkovitost $\mathrm{v}$ globalnih in regionalnih mrežah. $\mathrm{V}$ mnogo primerih mestno politiko oblikujejo kot odgovor na globalni gospodarski pritisk, da bi pritegnili kapitalske investicije in povečali konkurenčnost glede na druga mesta.

\section{Srednja in vzhodna Evropa: Opredelitev regije}

V zgodovini se je »srednje- in vzhodnoevropska regija dolgo mučila $\mathrm{z}$ nasprotujočimi si opredelitvami glede ozemeljske identitete in pripadnosti, z nacionalističnimi konflikti in z njihovim pogostim izrabljanjem $\mathrm{v}$ podporo geopolitičnim in geostrateškim interesom. Pogoste vojne in spreminjajoče se politične meje, ki so ozemlja prestavljale iz enega im- 
perija ali države v drugo, so iznakazile urbani razvoj, s tem ko so ustvarjale prava funkcionalna okolja revščine ter gospodarske, vojaške in politične nestabilnosti $\mathrm{v}$ mestih, katerih prebivalci so se morali vedno znova prilagajati novim okoliščinam. Malo je mest $\mathrm{v}$ regiji, ki so uživala ustaljeno medsebojno delovanje $\mathrm{Z}$ istim ozemljem; večina se jih je morala prilagajati novim političnim, socialnim in ekonomskim razmerjem v svojem prostoru.

Konec druge svetovne vojne in postavitev železne zavese sta dejansko uničila zgodovinske koncepte in funkcionalno resničnost »srednje Evrope« (Mitteleuropa) z njeno delitvijo na vzhod in zahod. Tako so v socialističnem obdobju v zahodnem svetu to regijo običajno poimenovali »vzhodna Evropa«. Šlo je za območje, ki je obsegalo Albanijo, Bolgarijo, Češkoslovaško, vzhodno Nemčijo (Nemško demokratično republiko ali DDR), Madžarsko, Poljsko, Romunijo in Jugoslavijo, tj. za območje med (tedanjo) SZ na vzhodu in meščanskimi družbami ali tržnimi ekonomijami Evrope na zahodu oz. članicami Nata. Dramatične spremembe po letu 1989 - zlom komunistične oblasti, razpad Sovjetske zveze, Češkoslovaške in Jugoslavije ter konec hladne vojne - so preoblikovale to regijo.

Srednja Evropa (ali točneje srednjevzhodna Evropa ) se je znova pojavila kot posebna subregija, ki obsega Češko republiko, Madžarsko, Poljsko, Slovaško in Slovenijo.

Čeprav je nekdanja vzhodna Nemčija zdaj v Evropski uniji (EU), je v nekem pogledu tudi del tega območja zaradi potencialno širšega regionalnega vpliva Berlina. Zelo posebna je tudi balkanska regija ali jugovzhodna Evropa, ki zajema nekdanje jugoslovanske republike Bosno in Hercegovino, Srbijo in Črno goro ter Makedonijo (FYROM) kakor tudi Albanijo, Bolgarijo in Romunijo. Hrvaška sebe lahko ima za obrobno in bolj za del srednje Evrope navzlic svoji razdeljenosti na območja, ki gravitirajo proti južni Panonski nižini, in območja s težiščem na obali Jadranskega (Sredozemskega) morja.

$Z$ razpadom ZSSR sta se pojavili še dve drugi posebni subregiji: prva so baltiške države Estonija, Latvija in Litva, druga pa je vzhodna Evropa, s katero danes opisujemo zahodna območja nekdanje Sovjetske zveze, namreč Belorusijo, Moldavijo, Ukrajino in v določenem pogledu tudi evropski del Rusije do Ura- la. Te regionalne podrazdelitve že v začetku napovedujejo, da bodo mesta $v$ srednji in vzhodni Evropi, ki so bila pod socializmom podrejena relativno visoki stopnji uniformnosti pri svojem razvoju (glej French in Hamilton, 1979), v'90. letih in tudi v predvidljivi prihodnosti doživljala mnogo več divergentnih sil in smernic. Vendar položaj ni statičen, ampak dinamičen in spremenljiv, kajti priključitev osmih srednje- in vzhodnoevropskih držav k EU leta 2004 že oblikuje smernice v mestih večjega dela srednje Evrope (Poljske, Češke Republike, Madžarske, Slovenije) in Estonije ( $\mathrm{tj}$. »prvega vala « kandidatk za EU v Agendi 2000 iz leta 1997) ter tudi Slovaške in drugih dveh baltiških držav Latvije in Litve, ki sta tudi postali članici EU leta 2004. Lahko pa bi nastal tudi učinek prelivanja (spill-over) na mesta $\mathrm{v}$ sosednjih kandidatkah za EU, kot so Hrvaška, Bolgarija, Romunija (znane kot kandidatke »drugega vala «) ali dolgoročno izključena ozemlja iz širitve EU (nekdanje jugoslovanske republike Bosna in Hercegovina, Srbija in Črna gora, Makedonija (FYROM) ter Albanija in vzhodnoevropske države Belorusija, Moldavija in Ukrajina).

\section{Spreminjanje mest}

V zgodnjih 90. je veljala predpostavka, morda tako na vzhodu kot zahodu, da bo tranzicija iz centralno vodenega državnega socialističnega gospodarstva $\mathrm{v}$ kontekstu enopartijskega (komunističnega) sistema $v$ tržno gospodarstvo in meščansko, demokratično družbo mesta v srednji in vzhodni Evropi dokaj poenoteno pognala po premočrtni poti. Le-ta naj bi sčasoma imela za posledico njihovo »konvergiranje «s prostorsko-strukturnimi in funkcionalnimi značilnostmi mest $\mathrm{v}$ razvitih tržnih gospodarstvih ali vsaj tistih v zahodni Evropi. Takšno razmišljanje pa ni bilo le naivno v luči kasnejše resničnosti, ampak je pogosto temeljilo na pomankljivem razumevanju »moči preteklosti« pri razločevanju mestnih smernic. V različni meri so sodobni razvoj in značilnosti mest $\mathrm{v}$ srednji in vzhodni Evropi odvisni od »prehojene poti « v njihovi predsocialistični kot tudi socialistični preteklosti. Torej lahko kot izhodišče vzamemo trditev, da sedanji prostorski model integracije med mesti odseva odtise vsaj treh »plasti « vplivov:

- prva je zelo zdiferenciran model zgodovinskih zapuščin izpred 1945-1949, ki vklju- 
čuje imperialno razdelitev regije, kakršna je bila večji del 19. st. (v nekaterih primerih do 1914-1918), učinke nacionalizmov in nastanek nacionalnih držav $\mathrm{v}$ letih 1918 in 1939-1941 ter različne posledice druge svetovne vojne za posamične države in njihova mesta

- druga je socialistično obdobje od poznih 1940. do 1989-1991. Medtem ko so bili zanj značilni visoka stopnja izoliranosti od ostalega sveta oz. zaprtosti pred njim (kot tudi pred drugimi socialističnimi drŽavami) po eni strani ter integracijski vplivi Sovjetske zveze po drugi, je to obdobje prineslo tudi nekaj pomembnih odstopanj med mesti v različnih državah, ker so vlade bodisi pričele spreminjati »poti v socializem « na način jugoslovanskega samoupravnega modela bodisi še strožje slediti sovjetskemu modelu;

- tretja vrsta vplivov uteleša učinke odpiranja mest širšim evropskim in globalnim

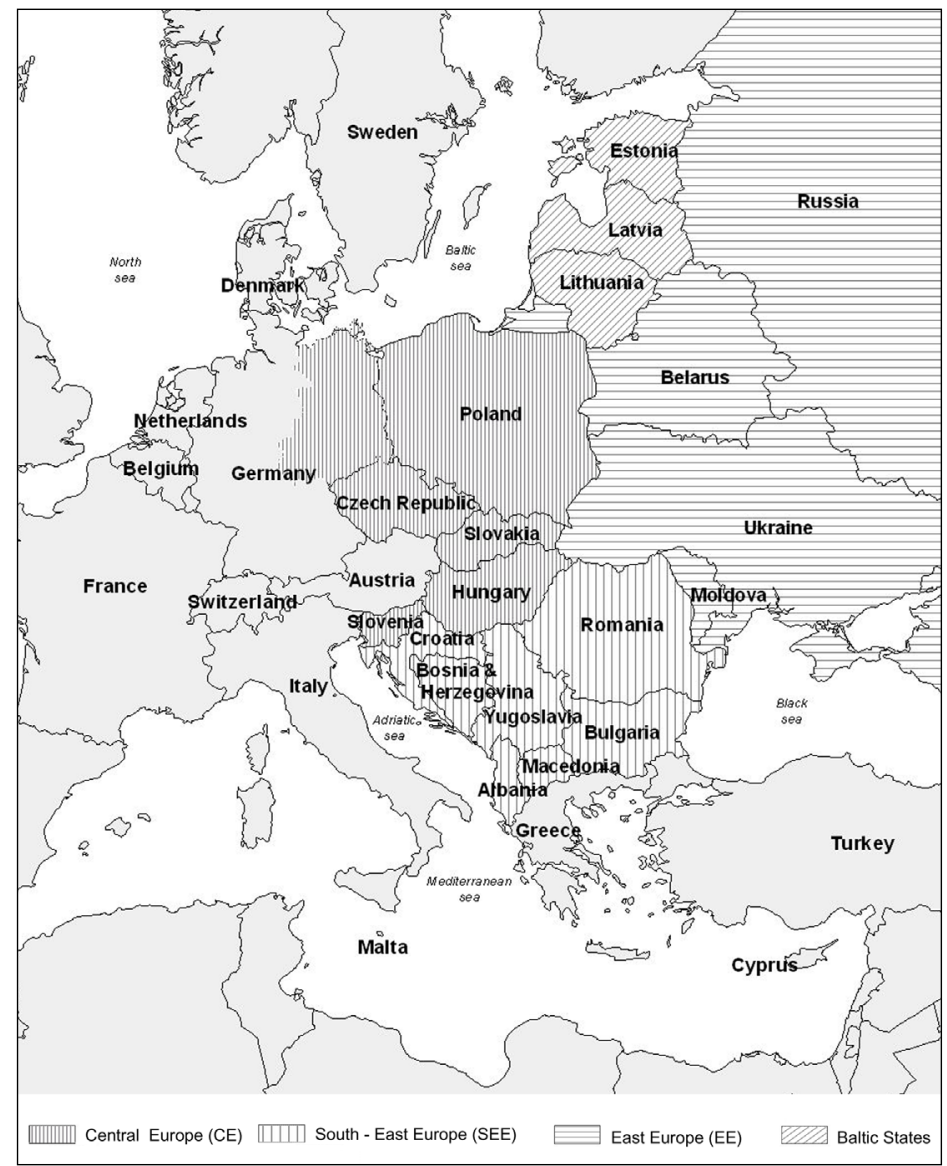

Slika 1: Srednja in vzhodna Evropa po letu 1989 (subregionalizacija) Vir: F. E. I. Hamilton, Kaliopa Dimitrovska Andrews in Nataša Pichler-Milanović (ur.) Transformation of Cities in Central and Eastern Europe: Towards Globalisation, Tokyo: UNU Press (pred izidom). silam - postsocialistično obdobje od konca 1980 - s prevzemanjem bolj tržno usmerjenih načel in praks, kar jih je vodilo v njihovo večjo ali manjšo integracijo ali reintegracijo v širši evropski in svetovni urbani sistem.

V zadnjem desetletju se zdi, da se pota mestnega razvoja in sprememb med mesti v srednji, jugovzhodni in vzhodni Evropi pomembno razhajajo. To se dogaja na različne načine, v različnih stopnjah in na različnih ravneh. Globalizacijske sile in vodenje prestrukturiranja nacionalnih gospodarstev navadno ustvarjajo razhajanja med: (i) glavnimi mesti in njihovimi regijami, kjer so učinki reform in prestrukturiranja najbolj izraženi, ter (ii) drugo- ali tretjerazrednimi in manjšimi mesti, kjer so lahko spremembe manj izrazite in bolj ozko omejene. In vendar se pomembna mednarodna diferenciacija dogaja tudi med urbanimi sistemi različnih držav kot rezultat večjih razhajanj v hitrosti, globini in zavezanosti reformam ali odporu proti njim s strani nacionalnih, mestnih ali lokalnih vlad.

\subsection{Tipologije spreminjanja mest}

Kot rezultat te »subregionalizacije « srednje in vzhodne Evrope lahko razlikujemo naslednje skupine ozemelj glede na njihove posebne značilnosti in smernice $\mathrm{v}$ preoblikovanju mest:

- mesta v nekdanji vzhodni Nemčiji, ki so se čez noč integrirala $\mathrm{v}$ nemško socialno tržno gospodarstvo in EU: »šok terapija « je imela za posledico radikalno spremenjena vzhodnonemška mesta. Berlin je poseben primer regeneracije in reintegracije, ker prevzema tudi funkcije glavnega mesta ponovno združene Nemčije znotraj EU in obenem leži blizu meje s Poljsko;

- mesta v »hitroprogaških « reformnih državah srednje Evrope in novih članicah EU, tj. v Češki republiki, na Madžarskem, Poljskem in v Sloveniji ter Estoniji med baltiškimi državami. Ta mesta doživljajo različne stopnje pretvarjanja produkcijskih faktorjev in proizvodnih zmogljivosti v tržno blago in so med mesti $\mathrm{v}$ regiji, ki so najbolj izpostavljena globalizacijskim in EU-izacijskim vplivom prek kapitalskih, informacijskih, človeških, tehnoloških in trgovinskih tokov. Bolj zanesljivo se približujejo mestom v tržnih gospodarstvih, kar 
je posledica odpravljanja industrije ali njenega prestrukturiranja, rasti proizvodnih in potrošnih storitev, izvajanja razpršenih tujih vlaganj ter pojava malih podjetij in podjetništva $\mathrm{v}$ kontekstu reorganizacije proizvodnih sistemov. Glavna mesta teh držav igrajo vodilno vlogo pri doseganju pomembnih premikov $\mathrm{v}$ gospodarskih gibanjih od recesije in propadanja $\mathrm{v}$ zgodnjih in srednjih 1990. k ekonomski rasti v srednjih in poznih 1990., v kar so se nekatera mesta vključila prej, druga kasneje;

- mesta v državah jugovzhodne Evrope, kjer so poskusi uvajanja tranzicije v glavnem obtičali, ker je njeno dejansko izvajanje izostalo tako po zaslugi vlad kot ljudi. Zato se tuji vlagatelji obotavljajo pri ustanavljanju kakršnihkoli večjih struktur. $\mathrm{V}$ teh mestih v Romuniji, Bolgariji ali v baltiških državah, kot sta Litva in Latvi$j a$, so v najboljšem primeru vidne vmesne stopnje preobrazbe, ker se ekonomsko propadanje nadaljuje, kar ima za posledico pomemben razvoj dejavnosti sive ekonomije. Prisotnost kakršnihkoli znakov globalizacije ali EU-izacije je zelo omejena;

- mesta v Ruski federaciji, kjer očitni poskusi »hitroprogaških « reform niso našli odziva v realnosti. Prvič, ustvarjena je bila virtualna ekonomija, ki jo nadzorujejo oligopolisti in mafijski elementi in ki se dejansko odmika od tržnih reform. Drugič, zaradi zloma močne osrednje vlade je za Rusijo značilen mozaik mestnih in regionalnih gospodarstev, kjer sta na enem skrajnem koncu mesti kot Moskva in St. Petersburg, ki doživljata zelo pomembno preobrazbo in integracijo/reintegracijo v evropsko in globalno gospodarstvo, na nasprotnem koncu pa so mesta, kjer vzporedno z državnimi ali neprestrukturiranimi privatiziranimi podjetji prevladujeta nedenarna menjava in siva ekonomija;

- mesta v državah vzhodne Evrope, kjer v bistvu še naprej gojijo socialistično gospodarstvo (Belorusija) ali pa ga $v$ resnici niso odpravili oz. podredili pravim tržnim reformam (Moldavija, Ukrajina). Ta so še močno izolirana od globalnih vplivov;

- mesta v nekdanji Jugoslaviji, ki so doživela vojno uničenje ali kaos, so bodisi fizično uničena (kot Sarajevo v Bosni in Hercegovini), tam se življenje trudi vrniti v normalnost bodisi jih še vedno oblikujeta dediščina vojnega gospodarstva (kot npr. Beograd v Srbiji) ali begunska problematika. V teh primerih imamo opraviti $\mathrm{Z}$ visoko stopnjo izoliranosti od razvoja $\mathrm{v}$ sosednjih regijah, da širšega sveta niti ne omenjamo. In vendar so tudi ta mesta deloma odvisna od učinkovanja mednarodnih procesov, ne nazadnje od sil $\mathrm{ZN}$ in drugih mednarodnih organizacij;

- mesta na ozemljih v sosedstvu območij, ki so bila predmet vojaških akcij in zato (morda) izkušajo učinek prelivanja balkanskega konflikta. Zlasti moramo omeniti nekdanjo jugoslovansko republiko Makedonijo (FYROM), kjer so mesta pod vplivom razbitja Jugoslavije, trgovskih embargov proti Srbiji, begunskih in etničnih problemov ter politične izolacije od Grčije. V mestih v Albaniji se po razbitju izolacije nekdanje socialistične države dogaja nagla transformacija $v$ neurejen razvojni model tretjega sveta.

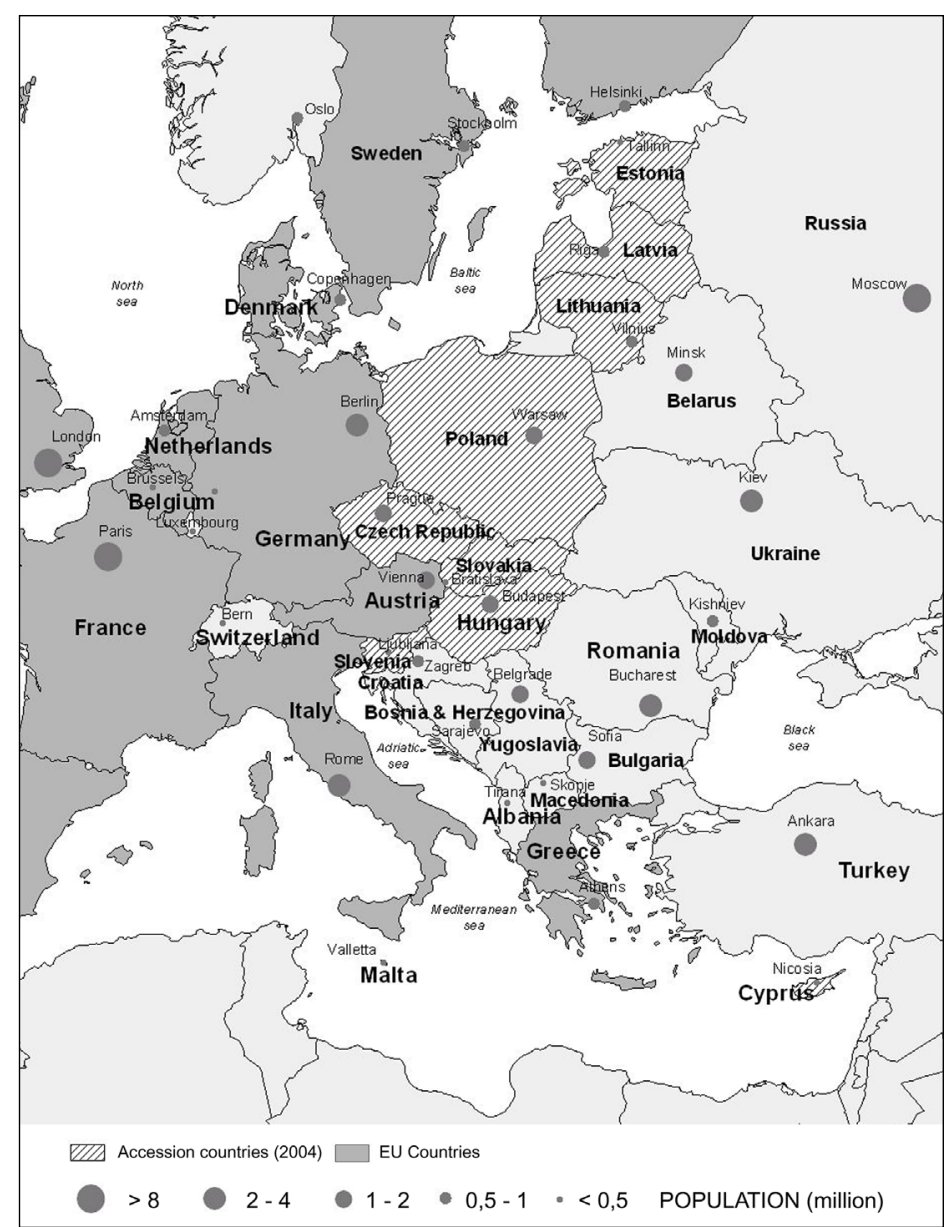

Slika 2: Šritev EU k srednji in vzhodni Evropi

Vir: F. E. I. Hamilton, Kaliopa Dimitrovska Andrews in Nataša Pichler-Milanović (ur.) Transformation of Cities in Central and Eastern Europe: Towards Globalisation, Tokyo: UNU Press (pred izidom). 
Treba pa je tudi upoštevati učinke politične in ozemeljske reorganizacije $\mathrm{v}$ srednji in vzhodni Evropi v 90. letih, ker ta na novo in na različne načine oblikuje vloge mnogo mest v regiji, in to ne le prestolnicah. Vseeno je treba poskusiti $\mathrm{z}$ uvodno klasifikacijo glavnih mest, kajti ta so predhodniki reform:

- Berlin je edinstveni primer, ker je edino mesto, ki mu je bila vrnjena vloga glavnega mesta $\mathrm{v}$ širšem, znova povezanem družbeno-ekonomskem in političnem prostoru - prostoru ponovno združene Nemčije. Načeloma bi to moralo imeti za posledico velike spremembe $\mathrm{v}$ mestu, kajti zdaj je prestolnica največjega evropskega gospodarstva po DBP-ju in ima za Moskvo največ prebivalcev;

- pet glavnih mest opravlja svojo funkcijo v kontekstu nespremenjenih državnih meja: Bukarešta, Budimpešta, Sofija, Tirana in Varšava. Celo v tem primeru se njihove izkušnje precej razlikujejo. Budimpešta, glavno mesto Madžarske, in Varšava, poljsko glavno mesto, imata glavni vlogi v hitro ali dokaj hitro rastočih in preoblikujočih se gospodarstvih. Sta tudi prestolnici držav, ki ležita ob EU in bosta kmalu vključeni vanjo. Na drugi strani pa so prestolna mesta Albanije, Bolgarije in Romunije v državah, ki jih muči gospodarsko nazadovanje (iz različnih razlogov), so bolj izolirane ali oddaljene od EU in utegnejo biti v bližnji prihodnosti iz nje še izključene;

- funkcionalni status neke druge skupine mest se je od leta 1991 pomembno povišal, ker so se ozemlja, na katerih izvajajo svojo jurisdikcijo, spremenila iz »polavtonomnih « regij republik znotraj večjih federalnih držav v neodvisne suverene države. To so Bratislava (Slovaška), Kijev (Ukrajina), Ljubljana (Slovenija), Minsk (Belorusija), Riga (Latvija), Sarajevo (Bosna in Hercegovina), Skopje (Makedonija), Talin (Estonija), Vilna (Litva) in Zagreb (Hrvaška). V teh primerih se moramo lotiti spreminjajočih se modelov prostorske in funkcionalne integracije, da bi razumeli, kako, zakaj in koliko je pridobitev statusa prestolnice vplivala na poti njihovega razvoja v primerjavi s prejšnjo vključenostjo $\mathrm{v}$ večje države. Znova pa bodo pomembne vloge igrali kontekst bližine ali oddaljenosti od EU, pristopanje k EU ali izključenost iz nje ter specifične okoliščine, kot je umeščenost na nekdanja balkanska vojna območja ali v njihovo bližino;
- glavna mesta večjih držav, ki še nadalje opravljajo prestolnično funkcijo, vendar so se po 1991. znašla v »skrčenih « nekdanjih suverenih državah: Beograd (Jugoslovanska federacija), Moskva (Sovjetska zveza) in Praga (Češkoslovaška). Pričakovali bi nazadovanje gospodarskih dejavnosti in funkcij, vendar se postavljata vprašanji, koliko tranzicija olajšuje prestrukturiranje in celo rast, kar je gotovo primer Moskve in Prage, in kako so na Beograd učinkovali vojaško dogajanje in mednarodne sankcije v 90. letih v nekdanji Jugoslaviji?

\subsection{Od glavnih mest do globalnih (»globalizirajočih «) mest}

Najpomembnejši prostorski učinek globalizacije je (ponovna) uveljavitev velikih metropolitanskih območij, še posebno prestolnic, kot a priori lokacij in ključnih vozlišč človeških dejavnosti.

Po združitvi leta 1989 je Berlin znova pridobil možnost postati evropsko politično in kulturno središče. Nastanek inovativnega gospodarstva temelječega na novih tehnologijah, komunikacijskih storitvah in (inter)nacionalnih funkcijah, podpira prizadevanje mesta, da bi dobilo status »globalnega « mesta (Krätke, 2001). Budimpešta, Praga in Varšava so se dvignile iz ranga nacionalnih mest na stopnjo mest evropskega pomena. Praga ima za Berlinom verjetno največji »globalizacijski potencial « (npr. turizem). Če se ozremo na njihove glavne mednarodne dejavnosti, je Praga postala močno kulturno, Budimpešta finančno in Varšava industrijsko središče srednje in vzhodne Evrope (glej Sykora, 1994, 1998). Med prestolnicami jugovzhodne Evrope si Sofija in Bukarešta prizadevata povzdigniti svoj status nacionalnih mest na raven evropske pomembnosti, vendar zaostajata za srednjeevropskimi prestolnicami zaradi makroekonomske omejenosti in periferne umeščenosti v Evropo.

Druge male prestolnice srednje Evrope, kot sta Ljubljana in Bratislava, ali pa baltiške prestolnice, Talin, Riga in Vilna, so (ponovno) dobile svojo mednarodno vlogo, ko so se formirale kot glavna mesta novih neodvisnih držav, pri čemer so ojačale svoj nacionalni položaj ter tudi mednarodnega ob pomoči čezmejnega in transnacionalnega sodelovanja 
ter s pristopnimi partnerstvi s članicami EU. Ljubljana ima npr. znatno primerjalno prednost vis-à-vis drugih srednje- in vzhodnoevropskih prestolnic zaradi čvrstosti nacionalnega in mestnega gospodarstva, kakovosti življenja ter institucionalne pripravljenosti na reforme. Ljubljana je eno najbolj konkurenčnih mest v srednji in vzhodni Evropi, ki pa mora še iti skozi proces temeljitejše internacionalizacije s preseganjem svoje majhnosti in dokaj slabe prepoznavnosti, s čimer bo okrepila svojo vlogo v čezmejnih »funkcionalnih mestnih sistemih « kot del procesa oblikovanja »svetovnega mesta «.

Druge nove prestolnice nekdanje Jugoslavije, Zagreb, Sarajevo, Skopje, so svoj status regionalnih središč spremenile v status mest nacionalnega pomena. Druge prestolnice jugovzhodne Evrope, kot sta Beograd in Tirana, so ohranile rang mest nacionalnega pomena, četudi zaostajajo za drugimi zavoljo političnih, gospodarskih in institucionalnih omejitev v svojih deželah. Nove prestolnice v vzhodni Evropi, kot so Minsk, Kijev in Kišinjev, so trenutno izolirane od globalnih procesov ter »dolgoročno « izključene iz procesov širitve in združevanja Evropske unije. Moskva je navzlic svoji umeščenosti na periferijo glede na evropska mesta podobne velikosti kot npr. London, Pariz ali Carigrad ohranila položaj mesta mednarodnega (če že ne »globalnega«) pomena, gradeč svoje konkurenčne prednosti na človeškem kapitalu in geostrateški lokaciji med Evropo in Azijo.

$\mathrm{V}$ danem trenutku nobene od srednje- ali vzhodnoevropskih prestolnic ne moremo imeti $\mathrm{za} »$ svetovno mesto $\ll \mathrm{v}$ tradicionalnem analitičnem pomenu, celo Moskve ne navzlic njeni velikosti in nekdanjemu vplivu na nekdanja socialistična mesta vzhodne Evrope. Berlin je verjetno edino mesto, ki bi se lahko povzdignilo do vloge »svetovnega mesta $\ll$ v bližnji prihodnosti in se pridružilo drugima dvema globalnima mestoma $\mathrm{v}$ Evropi, Londonu in Parizu. Enako velja za Dunaj v srednjeevropskem kontekstu. Vse ostale srednje- in vzhodnoevropske prestolnice še vedno internacionalizirajo svoje finančne, poslovne ali kulturne funkcije in obenem iščejo posamezne »niše «, da bi se specializirale $\mathrm{v}$ transnacionalnih (evropskih) ali čezmejnih (regionalnih) »funkcionalnih urbanih sistemih « ali specializiranih mestnih mrežah.

\section{Od »urbanih vozlišč $«$ do »območij metropolitanskega sodelovanja«}

Do leta 2000 je število prebivalstva srednje in vzhodne Evrope doseglo 125 milijonov, pri čemer jih 56 odstotka živi na urbanih območjih. Regija je, v celoti gledano, v obdobju po drugi svetovni vojni doživela najhitrejšo rast od vseh evropskih regij, vendar z velikimi razlikami med državami. Več kot polovica mestnega prebivalstva $\mathrm{v}$ srednji in vzhodni Evropi živi v mestih z manj kot 100.000 prebivalci, medtem ko je $\mathrm{v}$ mestih $\mathrm{s}$ 100.000 ali več prebivalci četrtina prebivalcev regije. V Estoniji in Latviji ter prav tako v Bolgariji in na Madžarskem je visoka koncentracija prebivalstva vidna predvsem v nacionalnih prestolnicah in njihovi okolici. V prestolnicah Poljske (Varšavi), Romunije (Bukarešti) ter Češke republike (Pragi), Litve (Vilni), Slovaške (Bratislavi), Slovenije (Ljubljani) in Albanije (Tirani) je zbran daleč manjši delež prebivalstva nacije (UNECE, 1997; UNCHS, 1996, 2001).

Nenehno prestrukturiranje mednarodnega gospodarstva in vedno večja odprtost nacionalnih meja nekaterim področjem koristita, nekatere pa spravljata v neugoden položaj, pri čemer je viden neenakomeren ekonomski in socialni razvoj. Ti procesi so v osnovi spremenili organiziranost in načine medsebojnega delovanja srednje- in vzhodnoevropskih mest uveljavljajoč povišane, čeprav različne stopnje njihove integracije $v$ mednarodni sistem mest. Vsi ti dejavniki spodbujajo nastajanje novega evropskega urbanega sistema ter specifičnih tipov in oblik urbanih mrež.

Pri oblikovanju urbane politike $\mathrm{v}$ srednji in vzhodni Evropi sta pomembni dve bistveni vprašanji. Prvo je vpliv mednarodnih organizacij in agencij na oblikovanje politike. Enako pomembno je drugo vprašanje, ki zadeva izvedbeno raven in se nanaša na oblike in funkcije metropolitanskih in lokalnih vlad ter na njihovo razmerje do (supra)nacionalnih teles (tj. EU, UN). Odvisno je tudi od upravne strukture mestnih regij, od institucij odgovornih za mestno upravo in planiranje ter od odnosov z lokalnimi in mednarodnimi finančnimi organizacijami, predvsem s Svetovno banko in Mednarodnim denarnim 
skladom. V procesih intra- in interurbanih preobrazb postsocialističnih mest je pomembna tudi vloga mednarodnih organizacij, multilateralnih in bilateralnih agencij. Prepletanje globalnih sil in lokalnih zahtev, tj. »globalno-lokalna naveza«, bi lahko imelo še druge posledice $\mathrm{v}$ preobrazbi mest srednje in vzhodne Evrope.

V začetku 90. let sta imeli v procesu oblikovanja tranzicijskih reform $v$ srednji in vzhodni Evropi največji vpliv Svetovna banka in Mednarodni denarni sklad. Njuna priporočila temelječa na tržnih načelih so bila usmerjena na cilje, kot so učinkovitost in proračunske omejitve. V drugi polovici 90. se je ob selektivnem širjenju OECD in Nata proti srednji in vzhodni Evropi (Češka republika, Slovaška, Madžarska, Poljska) in s pridružitvenimi sporazumi z EU proces političnega odločanja osredotočil bolj na sektorska (ponovna) prilagajanja, harmonizacijo zakonodaje, kooperacijo in razvoj institucij. Imenovane mednarodne agencije so svoje dejavnosti osredotočale na nacionalno raven in ne posebej na urbani razvoj kot tak.

Njihovo vlogo so dopolnjevali bilateralni in multilateralni sporazumi ter povezave in mreže med lokalnimi in regionalnimi oblastmi. Na drugem vrhu Središča za poselitev (Centre for Human Settlements) Združenih narodov (Habitat) v Carigradu (1996) so se urbani problemi in procesi političnega odločanja globalizirali, kar je imelo za posledico izdajo Habitat (»urbane«) Agende. Zdajšnji ukrepi lokalnih vlad $\mathrm{v}$ srednji in vzhodni Evropi, s katerimi bi ta priporočila vključili v svoje razvojne načrte, se razlikujejo v pogledu ugodnosti, ki bi jih s tem pridobila mesta, regije in posebne družbene skupine. Istočasno z dostopnostjo do skladov Evropske unije, $\mathrm{z}$ aplikativnimi raziskovalnimi in razvojnimi projekti kot delom procesa širitve in integracije EU spodbujajo bolj proaktivne čezmejne in transnacionalne vezi in partnerstva med različnimi dejavniki iz mest in regij članic EU ter iz srednje in vzhodne Evrope.

Odpiranje meja v srednjo in vzhodno Evropo, nastanek enotnega evropskega trga (1992) in pristop novih članic Avstrije, Švedske in Finske (1995) so zaostrili vprašanja zmožnosti preživetja in razvoja ter vloge različnih teritorialnih enot ( $\mathrm{tj}$. regij in mest) v družbenih, gospodarskih in poltičnih zadevah Evrope kot celote.
Zavezujoča odločitev za širitev v smeri srednje in vzhodne Evrope sprejeta na vrhu Evropskega sveta v Köbenhavnu (1993) je zahtevala nadaljne gospodarske reforme, harmonizacijo zakonodaje ter konsolidacijo institucionalnega razvoja. Odločitev je bila potrjena na Essenskem vrbu (1994) z oblikovanjem predpristopne strategije, ki je bila objavljena 1. 1997 kot Agenda 2000, znana tudi kot» Strategija širitve EU«. Po 1998. so se pričela uradna pristopna pogajanja s podpisom Pristopnih partnerstev (Accession Partnerships) in Sporazumov o pobratenju (Twinning Agreements) s »prvim valom pristopnic « oz. kandidatk - Estonijo, Češko Republiko, Madžarsko, Poljsko in Slovenijo, ki so bile znane kot Luksemburška skupina. L. 2000 jim je sledil »drugi val « kandidatk Bolgarija, Latvija, Litva in Romunija (t. i. Helsinška skupina). Evropski svet je v Nici (decembra 2000) znova potrdil politično prednost, ki je bila dana uspešni širitvi Evropske unije. Pristopna pogajanja s Češko republiko, Estonijo, Madžarsko, Latvijo, Litvo, Slovaško, Slovenijo, Ciprom in Malto so bila uspešno končana 16. aprila 2003 v Atenah s podpisom pristopne pogodbe in uradnim vstopom v EU maja 2004

Evropska unija v sklopu procesa $\gg$ ozemeljskega povezovanja « vedno bolj podpira vzpostavljanje različnih povezav in mrež med mesti in regijami $z$ namenom sodelovanja in udeležbe $\mathrm{v}$ skupnih projektih pod budnim očesom DG XVI (danes direktorat REGIO). Rezultati teh projektov imajo pomemben vpliv na oblikovanje »urbanih in regionalnih agend « Evropske unije, kot sta Evropa 2000 (1991) in Evropa 2000+ (1994), ki jima sledijo Evropske prostorske razvojne perspektive - European Spatial Development Perspectives (ESDP) (1999), Drugo pročilo o ekonomski in družbeni koheziji - Second Report on Economic and Social Cohesion (2001) in Tretje poročilo o ekonomski in družbeni kobeziji - Third Report on Economic and Social Cohesion (2004), slednje zahtevajo »večjo uravnoteženost in policentrični razvoj evropskega ozemlja «. ESDP je rezultat desetletje dolgega poskusa pripraviti agendo evropskega prostorskega načrtovanja kot področja politike. Na evropski ravni je dozorelo spoznanje o potrebi po oblikovanju politike in koordinacije na izvedbeni ravni predvsem kar zadeva okoljsko, prometno, kmetijsko, socialno in regionalno politiko. [3] Spodbujanje razvoja policentričnega 
in bolj uravnoteženega sistema metropolitanskih območij ter urbanih mrež je eden glavnih ciljev pri oblikovanju razvoja »policentričnega « evropskega urbanega sistema (ESDP, 1999, str. 21). ESDP lahko tolmačimo tudi kot poskus, da bi se lotili dvojnega procesa »notranje « evropske raznolikosti $\mathrm{Z}$ »zunanjim « konkurenčnim pritiskom Severne Amerike in Azije.

\section{1 »Evrokoridorji«: prometne povezave in dostop do znanja}

Razvoj evrokoridorjev je eno najpomembnejših konceptualnih orodij za povezovanje politik, ki se nanašajo na razvoj »multimodalnega sodelovanja med mesti, izboljšanje infrastrukture, telekomunikacij in prometa na bolj obrobnih območjih, na zmanjšanje zastojev ter na medcelinsko dostopnost « itd. (ESDP, 1999, str. 61). Takšni koridorji veliko prispevajo $\mathrm{k}$ ozemeljskemu povezovanju Evrope. [4] Nekateri so že vključili nekaj postsocialističnih mest srednje in vzhodne Evrope (npr. Pariz-StrasbourgStuttgart-München-Dunaj-Budimpešta, ali Bruselj-Köln-Hannover-Berlin-Poznan-Varšava), vendar je bistvene manjkajoče člene še potrebno zgraditi.

Sodelovanje med mesti in regijami v Evropi še nadalje krepijo različni programi Evropske unije namenjeni srednji in vzhodni Evropi (npr. Interreg, Phare, Tacis, Ecos/ Overture, okvirni programi itd.), ter druge oblike bilateralnega in multilateralnega čezmejnega in transnacionalnega sodelovanja. Sodelovanje na področju prostorskega planiranja $v$ Evropi je omogočilo nastanek novega instrumenta planiranja: transnacionalnih prostorskih vizij. Dva transnacionalna kooperacijska dokumenta, znana kot »VASAB 2010+« (namenjen 11 državam baltiške regije) in »VISION PLANET « (za 12 držav v regiji CADSES: srednejevropski, jadranski, donavski in jugovzhodnoevropski prostor), ponujata strateške smernice, prilagojene prostorskim potrebam za razdeljevanje skladov EU v sklopu predpristopne pomoči srednjein vzhodnoevropskim državam (programi PHARE, ISPA in SAPARD).[5]

Glede na prostorske razvojne projekte sta pobudi EU INTERREG II in za njo INTERREG III najpomembnejša programa, ki se ukvarjata s transnacionalnim sodelovanjem, ter sta $v$ povezavi s programom PHARE (čezmejno sodelovanje) pomembna instrumenta za uveljavitev ESDP-ja v srednji in vzhodni Evropi.[6]

\subsection{Evropske metropolitanske regije: nova »globalna integracijska območja $a$ ?}

ESDP izpostavlja posebne vloge mest, ki bi jih lahko prevzela z evropskimi koridorji, globalnimi integracijskimi conami, vstopnimi mesti, urbanimi grozdi in posameznimi urbanimi poli v podporo boljše ozemeljske uravnoteženosti znotraj razširjene EU. Razširjena EU bo vključevala številne urbane regije, mala in srednjevelika mesta, različna ruralna zaledja, gorske regije in prav tako tudi otoke. Novi evropski urbani sistem bo vključeval določeno število metropolitanskih območij, ki bodo opravljala funkcijo prestolnic in imela dominanten položaj v nacionalnih urbanih sistemih. Po zadnji širitvi Evropske unije bo približno 70 večjih mest $z$ več kot 500.000 prebivalci prevladovalo $\mathrm{v}$ evropskem urbanem sistemu. Okoli 20 odstotkov prebivalstva nove Evropske unije ( $\mathrm{tj}$. 27 članic) živi v teh mestih.

ESDP označuje »peterokotnik«(Pentagon), ki ga sestavljajo London, Paris, Muenchen, Milano in Hamburg kot prevladujočo jedrno regijo (core region) Evrope in $\mathrm{v}$ tem trenutku edino evropsko »območje globalnega pomena«. Upoštevajoč uravnoteženi razvoj in policentrizem razširjene EU se bodo »peterokotnemu « jedru pridružila nova »območja čezmejnega metropolitanskega sodelovanja «; slednja se bodo prizadevala doseči status »globalnih integracijskih območij « kot dinamičnih, globalnih grozdov mednarodno lahko dostopnih metropolitanskih regij, ki bodo geografsko dobro porazdeljene po evropskem ozemlju.

(Transnacionalne) politične spodbude $\mathrm{Z}$ vrha, na znanju temelječe dejavnosti in finančna podpora EU v povezavi s pobudami od spodaj, nastalimi med mesti in regijami, ki si najdejo partnerje in osnujejo institucionalne povezave in mreže, naj bi stimulirale nove strukture sodelovanja ter zavezujoča partnerstva, v katera bodo vključena sosednja (čezmejna) metropolitanska območja, večja in manjša mesta ter ruralna zaledja (glej Mehlbye, 2000; Faludi, 2002). 
Danes se soočamo $z$ rastočo potrebo po razjasnitvi ozemeljskih značilnosti globalizacijskih procesov v evropskem merilu, ki so relevantne za razvoj »globalnih integracijskih območij «. Od leta 2000 se opravljajo analize družbeno-ekonomskih in ozemeljskih specifičnosti in profilov metropolitanskih območij Evrope, da bi bolje razumeli podobnosti ter prikazali sinergijske potenciale za sodelovanje, ki jih navaja ESDP. Sedanje raziskovanje na evropski ravni, ki zadeva nova »globalna integracijska območja«, je tudi plod transnacionalnih raziskovalnih mrež ter ustanovitve Evropske opazovalne mreže za prostorsko načrtovanje - European Spatial Planning Observatory Network (ESPON).[7]

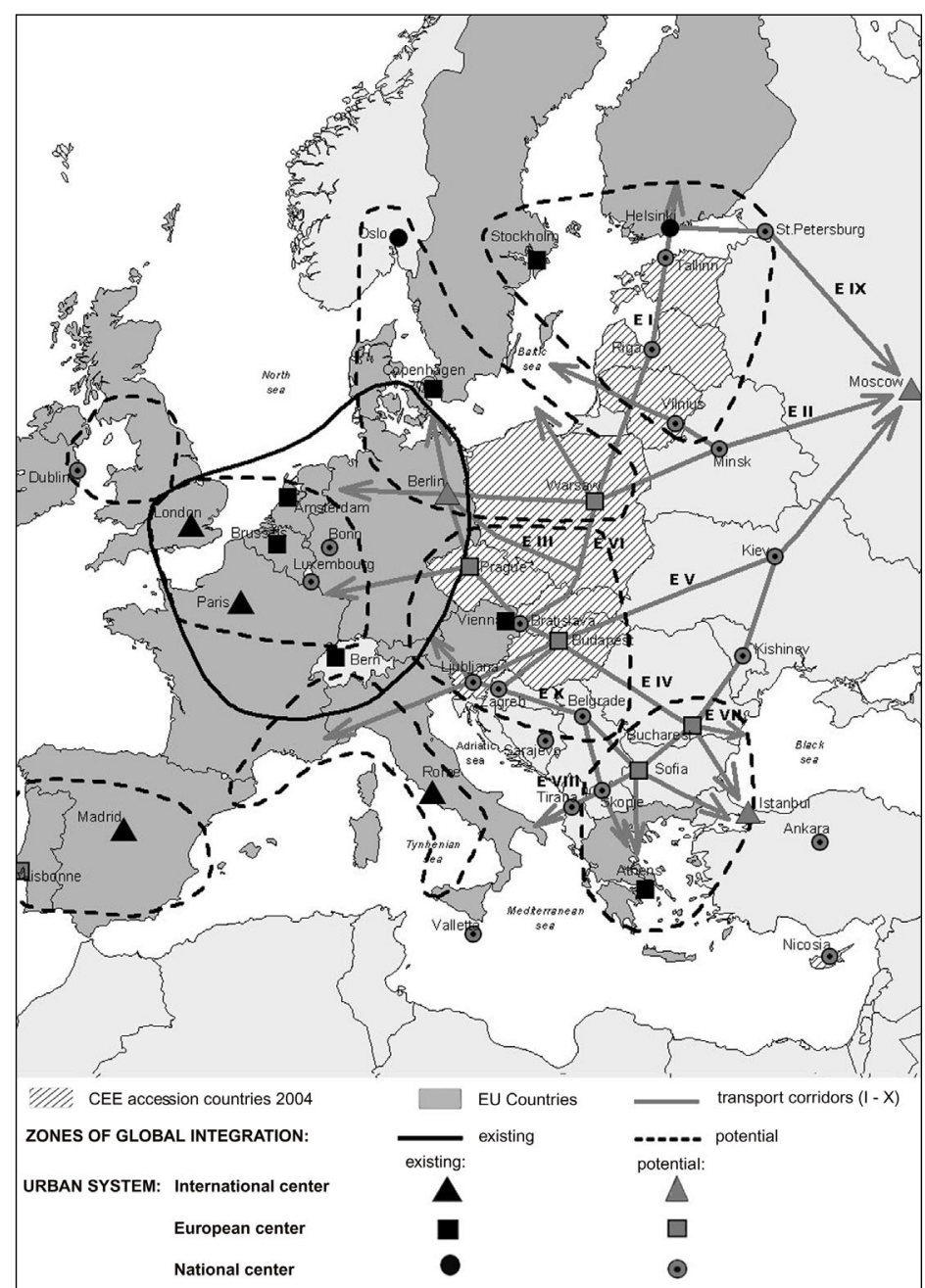

Slika 3: Novi evropski urbani sistem ali globalno »integrirano območje« metropolitanskega sodelovanja?

Vir: F. E. I. Hamilton, Kaliopa Dimitrovska Andrews in Nataša Pichler-Milanović (ur.) Transformation of Cities in Central and Eastern Europe: Towards Globalisation, Tokyo: UNU Press, (pred izidom). Na osnovi: Read, 2000; Mehlbye, 2000; Faludi, 2002, ESDP, 1999.

\section{Sklep - Interurbane spremembe $\mathrm{v}$ srednji in vzhodni Evropi: globalizacija, »evropeizacija $a$ in čez-mejna regionalizacija}

Srednjeevropske države (Češka Republika, Slovaška, Madžarska, Poljska, Slovenija) in baltiške države (Estonija, Latvija in Litva) so iz političnih, ekonomskih in strateških razlogov maja 2004 postale polnopravne članice EU. Bolgarija in Romunija jim bosta kmalu sledili - leta 2007. Države »nepristopnice« jugovzhodne Evrope (Albanija, Bosna in Hercegovina, Hrvaška, FYR Makedonija, Srbija in Črna Gora, imenovane zahodni Balkan) ter vzhodnoevropske države (Belorusija, Moldavija in Ukrajina) so zaenkrat izključene iz procesa širitve EU, a imajo možnost priključitve $\mathrm{v}$ naslednjem desetletju pod pogojem, če bodo ugodile zahtevam širitve Evropske Unije.

Proces širitve bo utrdil položaj Evrope na svetovnem prizorišču. Pristop srednje- in vzhodnoevropskih držav k članstvu Evropske unije predpostavlja omejeno nadaljevanje delovanja globalnih sil oziroma globalizacije prek povezav in mrež med različnimi partnerji iz evropskih mest in regij. Zato so po leta1994 sile evropeizacije $\mathrm{v}$ obliki čezmejne regionalizacije ali različnih sodelovanj med srednjein vzhodnoevropskimi državami ter članicami EU močnejše od sil globalizacije ali integracije srednje- in vzhodnoevropskih mest $\mathrm{v}$ svetovne mreže. Iz te perspektive inter in intra-urbano preoblikovanje postsocialističnih mest $\mathrm{v}$ srednji in vzhodni Evropi ni videti kot edinstveni fenomen per se, ampak bolj kot rezultat globalnih procesov znotraj specifičnih prostorskih in časovnih kontekstov.

Končni izid procesa preoblikovanja mest $\mathrm{v}$ srednji in vzhodni Evropi je še negotov in se utegne razlikovati po subregijah (srednja, jugovzhodna, vzhodna Evropa). Kot posledica hkratnega delovanja »zunanjih « in »notranjih « sil v zadnjem desetletju si srednje- in vzhodnoevropska postsocialistična mesta postajajo nekako podobna, medtem ko si prizadevajo odpraviti negativne učinke socialistič- 
nega razvoja in učvrstiti svoj mednarodni položaj. Kumulativni učinki procesa preoblikovanja na inter- in intraurbani razvoj so v bistvu povečevanje mednarodne konkurenčnosti, krepitev sodelovanja in mrežnega povezovanja, oživljanje mest, prepoznavnost srednje- in vzhodnoevropskih mest, poudarjanje njihove kulturne dediščine, lokalne identitete ter usmerjenost $\mathrm{v}$ trajnostni razvoj.

Prihodnost teh mest ni odvisna le od njihove (pred)socialistične dediščine ali uspešnosti pri privzemanju bolj tržno usmerjenih načel, vzpostavitve učinkovite javne ureditve/nadzora in uspešnosti mestne uprave, ampak tudi od njihove (re)integracije v različne evropske in globalne mreže. Mreža prestolnic je dandanes najbolj dinamičen proces ozemeljske integracije $\mathrm{v}$ evropskem merilu. Istočasno bi tudi »specializirano « in »tematsko « sodelovanje lahko spreminjalo oblike urbanega mrežnega povezovanja ter pospeševalo manj hierarhične organiziranosti mest, kar bi vodilo k bolj policentrični strukturiranosti Evrope. Zatorej so ta mesta »motorji « ozemeljskega povezovanja v Evropi. Metropolitansko grozdenje specifičnih čezmejnih mestnih mrež pri vzpostavljanju »globalnih integracijskih območij « je nov teritorialni koncept, ki je sestavni del evropskega integracijskega procesa. Nanj se gleda kot na eno najpomembnejših sestavin v naporih za zagotavljanje trajnostnega razvoja ter boljšega ozemeljskega ravnotežja v Evropi. Povezovanje manjših in večjih mest, metropolitanskih območij in njihovih zaledij med seboj preko infrastrukture in strateškega sodelovanja ter oblikovanje policentričnih urbanih regij bi lahko pripeljalo do oblikovanja dinamičnih »globalnih integracijskih območij «. Splošni cilj je »pronicanje« koristi uspešnega družbenega in gospodarskega delovanja skozi urbani sistem ter istočasna krepitev globalnega konkurenčnega položaja Evrope kot celote. Če bi se ta vizija ozemeljskega povezovanja uresničila, bi se konkurenčni potenciali in globalni položaj srednjein vzhodnoevropskih mest izboljšali. Na dosežke teh mest in na način njihovega razvoja bodo globoko vplivala medsebojna delovanja tako »globalnih« kot »lokalnih« kontekstov in v širšem pomenu razvoj gospodarstva, politike in družbe.

Mag. Nataša Pichler-Milanović, M. Sc. (Econ.), univ. dipl. prost. planer., univ. dipl. geogr., Univerza v Ljubljani, Filozofska fakulteta, Ljubljana

E-pošta: natasa.milanovic@ ff.uni-lj.si

\section{Opombe:}

[1] Članek v glavnem temelji na uvodnih in sklepnih poglavjih knjige, ki bo kmalu izšla:

F. E. I. Hamilton, Kaliopa Dimitrovska Andrews, and Nataša-Pichler-Milanović (Eds.) Transformation of Cities in Central and Eastern Europe: Towards Globalisation, Tokyo: UNU Press, 2004.

[2] Klasični primer je Japonska, kjer vlada ob podpori močnih poslovnih interesov izvaja nepopustljivo in spremenljivo politiko strogega omejevanja uvoza in neposrednih tujih naložb, medtem ko odločno podpira izvoz (Longworth, 1998)

[3] Za primerjavo naj navedem, da $v$ državah članicah polovica mestnega prebivalstva živi $v$ mestih $\mathrm{s}$ 100.000 ali več prebivalci.

[4] Transevropsko omrežje, ki so ga 1992 leta sprva predlagali za zahodno Evropo in se leta 1996 uradno o njem dogovorili, je bilo razširjeno $v$ skladu $z$ odločitvami sprejetimi na vseevropskih konferencah prometnih ministrov na Kreti (1994) in v Helsinkih (1997) o vključitvi 10 »multimodalnih koridorjev«, ki naj bi se priključili na infrastrukturo srednje- in vzhodnoevropskih držav pristopnic.

[5] PHARE: program čezmejnega sodelovanja z državami pristopnicami iz srednje in vzhodne Evrope; ISPA: Instrument strukturnih politik v predpristopnem obdobju; SAPARD: Predpristopna pomoč Skupnosti za prestrukturiranje kmetijstva in razvoj podeželja.

[6] Programi INTERREG IIIB so bili sproženi po vsej evropski celini za naslednja območja: zahodno Sredozemlje, alpski prostor, atlantsko območje, jugozahodno Evropo, severozahodno Evropo, severnomorsko območje, CADSES, severni rob in ArchiMed (srednje- in vzhodnosredozemski prostor: Italija, Grčija, Ciper, Malta)

[7] Program ESPON je bil osnovan leta 2001 kot sodelovanje med državami članicami EU, Evropsko komisijo in državami pristopnicami pri izdelavi in izvajanju ESDP v programu INTERREG III. Več informacij je na voljo na www.espon.lu.

\section{Viri in literatura}

Andrusz, Gregory, Harloe, Michael in Szelenyi, Ivan (ur.) (1996) Cities After Socialism: Urban and Regional Change and Conflict in Post-Socialist Societies, Blackwell Publishers, Oxford.

Brenner, Neil (1999) Globalisation as Reteritorialisation: The Re-scaling of Urban Governance in the European Union, Urban Studies, Vol. 36, št. 3, str. 431-451.

György, Enyedi (1992) Urbanization in East Central Europe: Social Processes and Societal Responses in the State Socialist Systems, Urban Studies, Vol. 29, št. 6, str. 869-880.

Györgyi, Enyedi, ur. (1998) Social Change and Urban Restructuring in Central Europe, Akadémiai Kiadó, Budapest.

Faludi, Andreas ur. (2002) European Spatial Planning, Lincoln Institute of Land Policy, Cambridge Massachusetts.

French, R. Anthony, Hamilton, Ian, F., E. ur. (1979) The Socialist City: Spatial Structure and Urban Policy, John Wiley, New York. 
Friedman, John, Wolff, Goetz (1982) World City Formulation: An Agenda for Research and Action, International Journal of Urban and Regional Research, št. 6, str. 309-344.

Friedman, John (1986) The World City Hypothesis, Development and Change, št.17, str. 69-83.

Friedman, John (1995) Where We Stand: A Decade of World City Research. V: Knox, Paul L. in Taylor, Peter J., ur. (1995) World Cities in a World System, Cambridge University Press, Cambridge, str. 21-47.

Friedman, John (2001) World City Revisited: A Comment, Urban Studies, Vol. 38, št. 13, str. 2535-2536.

Giddens, Anthony (1990) The Consequences of Modernity, Polity Press, Cambridge.

Giddens, Anthony (1996) Globalisation: A Keynote Address, UNRISD News, št. 15, str. 15.

Ghanbari-Parsa, Ali in Moatazed-Keivani, Ramin (1999) Development of Real Estate Markets in Central Europe Environment and Planning A, Vol. 31, str. 1383-1399.

Hegedüs, József, Mayo, Stephen E. in Tosics, Iván (1996) Transition of the Housing Sector in the East Central European Countries, Review of Urban and Regional Development Studies, št. 8, str. 101-136.

Held, David, McGrew, Anthony, Goldblatt, David in Perraton, Jonathan (1999) Global Transformations: Politics, Economics of Culture, Polity Press, Cambridge.

Hirst, Paul in Thompson, Graham (1996) Globalisation in Question: The International Economy and the Possibilities of Governance, Polity Press, Cambridge.

Keivani, Ramin, Parsa, Ali in Mc Greal, Stanley (2001) Globalisation, Institutional Structures and Real Estate Markets in Central European Cities, Urban Studies, Vol 38, št. 13, str. 2457-2476.

Knox, Paul L. in Taylor, Peter J. ur. (1995) World Cities in a World System, Cambridge University Press, Cambridge.

Krätke, Stefan (2001) Berlin: Towards a Global City? Urban Studies, Vol. 38, št. 10, str.1777-1799.

Kennedy, Michael in Smith, David A. (1989) East-Central European Urbanization: A Political Economy of the World-System Perspective, International Journal of Urban and Regional Research, Vol. 13, št. 4, str. 597-624.

Lo, Fu-chen in Yeung, Yue-Man, ur. (1998) Globalization and the Worlds of Large Cities, UNU Press, Tokyo. Longworth, Ron (1998) owhere are the winds of globalization sensed with more apprehension than on the continent of Europe, Global Squeeze, str. 151.

Marcuse, Peter in van Kempen, Ronald ur. (2000) Globalizing Cities: A New Spatial Order, Blackwell Publishers, Oxford.

Mehlbuy, Peter (2000) Global Integration Zones Neighbouring Metropolitan Regions in Metropolitan Clusters, Informationen zur Raumentwicklung, št. 11/12.

Musil, Jiří (1993) Changing Urban Systems in PostCommunist Societies in Central Europe: Analysis and Predictions, Urban Studies, Vol. 30, št. 6, str. 899-906. Ohmae, Kenichi (1990) The Borderless World, Collins, London.

Ohmae, Kenichi (1995) The End of the Nation State, Free Press, New York.

Pichler-Milanovich, Natasha (2001) Urban Housing Markets in Central and Eastern Europe: Convergence,
Divergence or Policy Collapse, European Journal of Housing Policy, Vol. 1, št. 2, str. 145-187.

Reed, Roger (2000) Chances and Potentials of Networks in Supporting Future-oriented Development in Metropolitan Regions, Informationen zur Raumentwicklung, št. 11/12, str. 737-743.

Rosenau, James N. (1997) Along the Domestic-Foreign Frontier, Cambridge University Press, Cambridge.

Sassen, Saskia (1991) The Global City: New York, London, Tokyo, Princeton University Press, Princeton, NJ.

Sassen, Saskia (1994) Cities in a World Economy, Pine Forge Press, Thousand Oaks, CA.

Sỳkora, Luděk (1990) Local Urban Restructuring as a Mirror of Globalization Processes: Prague in the 1990s, Urban Studies, Vol. 7, št. 31, str. 1149-1166.

Sỳkora, Luděk (1998) Commercial Property Development in Budapest, Prague and Warsaw. V: Enyedi, Györgyi, ur. (1998) Social Change and Urban Restructuring in Central Europe, Akadémiai Kiadó, Budapest, 1998, str.109-136.

\section{Poročila}

CEC (Commission of the European Communities), Europe 2000: Outlook for the development of the Community«s territory, Luxembourg: Office for Official Publications of the European Communities, 1991.

CEC (Commission of the European Communities), Europe 2000+: Cooperation for European territorial development, Luxembourg: Office for the Official Publications of the European Communities, 1994.

CEC (Commission of the European Communities), European Spatial Development Perspectives: Towards balanced and sustainable development of the territory of the EU, Luxembourg: Office for the Official Publications of the European Communities, 1999.

CEC (Commission of the European Communities), Unity, solidarity, diversity for Europe, its people and its territory: Second Report on Economic and Social Cohesion, Luxembourg: Office for the Official Publications of the European Communities, 2001.

CEC (Commission of the European Communities), $A$ new partnership for cohesion: convergence, competitiveness, cooperation, Third Report on Economic and Social Cohesion, Luxembourg: Office for the Official Publications of the European Communities, 2004.

EC (European Commission), Agenda 2000: For a Stronger and Wider Union, Brussels: European Commission, 1997.

United Nations Economic Commission for Europe (UNECE), Human Settlement Trends in Central and Eastern Europe, New York and Geneva, United Nations, Economic Commission for Europe, 1997.

United Nations Centre for Human Settlements (UNCHS - Habitat), An Urbanising World: Global Report on Human Settlements, Oxford: Oxford University Press, 1996. United Nations Centre for Human Settlements (UNCHS - Habitat), The State of the World«s Cities, Nairobi: UNCHS, 2001.

VASAB 2010, Vision and Strategies around the Baltic Sea 2010, Towards a Framework for Spatial Development in the Baltic Sea Region, 1996.

VISION PLANET, Strategies for Integrated Spatial Development of the Central European Danubian and Adriatic Area, Guidelines and Policy Proposals, 2000. 